\title{
Present Status of Garment workers in Bangladesh: An analysis
}

\author{
Md Zafar Alam Bhuiyan \\ Lecturer of Fashion Design \& Assistant Proctor, Shanto-Mariam University of Creative Technology Dhaka, \\ Bangladesh
}

\begin{abstract}
Garments sector is the life blood of Bangladesh as the agricultural land has there been turned to a country of garments industries. Employment in the Ready-made garment sector in Bangladesh provides workers with economic benefits and some empowerment. More than 3.2 millions people are working in this sector and about 5000 garments factories are scattered across the country. 78 per cent of our foreign earnings come from this sector. So it will not be an overstatement to say that, we earn our bread from garments industries. The study attempts to explore the present socio-economic status of the garments workers. The study based mainly on economic and social status of 100 garments workers from Rampura and Badda areas of Dhaka City. It was found that the socio-economic condition of the Garments workers is not in a lofty stage. Amongst the workers about 70 per cent are women, who work dawn to dusk even up to late night when their wages are not in the satisfactory level. They cannot afford their foods, cloths, housing, medicines, and educations of their wards as they are ill paid. On the contrary, their children are deprived from their care; they suffer from malnutrition and unhygienic complexities. They have no time or scope for recreation. During the study it was found that, worldwide economic meltdown has affected RMG sector of Bangladesh as some workers have lost their jobs and trend of works have been declined. At the end of the study, some recommendations were placed to improve the present conditions of the garments workers as well as garments sector of the country.
\end{abstract}

\section{Bangladesh is the country of Garments Industries:}

Bangladesh is a developing country. Most of the people are still occupied in agriculture sector. But per capita land is very scant. Most of our farmers are the marginal farmers. Others rural workforce is involved with day labors, nonetheless some people are engaged in others small scale industries like handicrafts which are yet to booming to earn huge currency to involve the enormous unemployed persons. The Successful export oriented readymade garments (RMG) industry of Bangladesh has observed remarkable growth since its beginning late 1970s. Paradoxically, this flagship industry of Bangladeshi private entrepreneurial talent took roots through the first export consignment of shirts from Bangladesh made by state trading agency, the Trading Corporation of Bangladesh (TCB) in the mid -1970s (Rashid, 2006), under the country trade administration \& the destination was some East European Countries. Subsequently, however, private entrepreneurs entered the industry and phenomenal growth took place in RMG exports from Bangladesh. Export of RMG increased from US \$40 thousand in 1978-79 to US $\$ 6.4$ billon in 2004-05.The industry has also provided employment to nearly 2.8 million workers (BGMEA, 2009) most of them women drawn from the rural areas.

Explosive growth of RMG exports is of not inimitable to Bangladesh. The annual compound growth rate of RMG export industries in Indonesia (31.2\%), Mauritius (23.8\%) \& Dominican Republic (21.1\%) compares favorably with that of Bangladesh (81.3\%) over the 1980-87 periods. However, while the initial conditions were favorable for export growth in the countries noted above, this was far from the truth in case our country. This makes research into the factors responsible for the observed outstanding growth of RMG exports from Bangladesh-a persuasive case study in economic development.

Academics and researchers have generally attributed the remarkable growth of RMG export from Bangladesh to favorable external conditions, notably the Multi-Fiber Arrangement (MFA) bilateral quota system imposed by developed apparel countries, and low wages in Bangladesh. The role played by supportive government policy has also been noted in these studies. This noticeable incredulity in the dynamics and creativity of Bangladeshi RMG entrepreneurs seems to have sprung from the more general conception, widely held by many scholars during the 1970s and 1980s, that Bangladesh lacks industrial possessions.

As we have seen above that, rising of RMG industry in Bangladesh occurred during a time when the economy's health was poor shaped and it was plagued by various problems both structural and policy-induced in nature, which inhibited, among other things, growth of manufacturing industries in the country, the work forces related to this, including govt. had to fight a lots to peruse these from the each corner, while inappropriate government policy can spell digester for an industry, by the same logic, sound economic policy of the government can stimulate industrial growth. There is unanimity of opinion among scholars that the changing structure of the global apparel industry has been uniquely fashioned by the MFA Quota system used by the developed importing countries which restricted export supplies of garments to these markets from the established supplying countries and thereby paved the way for the emergence of new garments exporting 
countries. This migration of the export oriented garments industry from the established suppliers to the new suppliers was, as one would expect, directed by the existence of the wages in the new exporting countries.

Before the innovation of Garments industry of late 1970s the unemployed were the burden to the Agro based economy of Bangladesh. Then the following social problems were found in the rural areas of Bangladesh which used lead the country as a country of poor, poorly developed infra structures, lack of education, Social unrest, Malnutrition, Marriage in underage, Polygamy, Dirty village politics.

\subsection{THE RISE OF READYMADE GARMENTS IN BANGLADESH:}

Generally an industry initially develops to domestic demand, and then subsequently turns to export once it becomes matured. The evolution of garments industry in Bangladesh, as in most CBI and Sub-Saharan countries, has not followed this pattern. Instead of growth being supped by domestic demand, the rise of RMG industry in Bangladesh can be attributed to growing demand in developed countries for cheap apparel. But it should be noted that there was a small domestic garments industry in the - then East Pakistan in 1960s which created demand in West Pakistan. The mercury shirt, a company located in Karachi, sourced a few consignments of shirts during 1965-68 made by some tailoring outfits operating in Dhaka and the exported these to some European countries. There were few tailoring shops in Dhaka who made garments a small quantity of export-quality shirts and children wears on specific orders. Mainly they received orders from West Pakistan (Karachi -based firm) \& supply thereafter. However there was very little investment in that time. Of course, the involvement was also very little as it was in the initial stage.

During the early eighties, the government issued licenses to many entrepreneurs for the duty free importation of machinery to produce garments for export for export purposes. Consequently, the number of firms in the garments industry increased rapidly and reached 632 in 1984-85, a phenomenal growth in deed as shown in the table 1.Bangladesh exported its garments to the North American and European Markets in the early eighties; at that time, its export were not subject to MFA Quotas in these markets, hence the spectacular growth. However, the very rapid growth of imports of apparel from Bangladesh prompted the US, Canada and the European countries to impose the MFA Quotas on Bangladesh's garments export.

This had temporarily showed down growth of RMG industry in Bangladesh; there was a restrained increase in the number of firms from 744 in 1985-86 to 804 in 11989-90. Export growth had also slowed down somewhat during 1985-90 period. However, the industry bounced back from 1990 onwards.

According to the BGMEA, there were 4300 member firms in 2004-05 which 2275 were woven garments units, 700 were knitted factories, and 525 were sweaters; however, 133 of these were closed in addition, there were 560 units which were exclusive members of the Bangladesh Knitwear Exporters and Manufacturers Association (BKMEA).Thus the total number of active firms producing garments in Bangladesh was woven units, 42 percents knit units, and 11 percent producing sweaters. Total employment generated by these enterprises is estimated to be 1.9 million production workers, or 2 million if all employees are included .Most of these workers (an estimated 80 percent) are women from the rural areas.

The number of garments factories shot up to some 3000 in 2002 and by 2005 it reached 3560.By 200405 exports had reached US\$ 6.4 billion. The average growth rate of export during 1990/91-1997/98 was almost 21 percent per year. However, the growth rate of export declined in the 1998/99-2004/05 period mainly due to exogenous factors like flood in 1988, the global recession in 2000, and the 11 September incidents in the US the garments following year. The share of garments export earnings of Bangladesh climbed from 3.89 percent in 1983-84 to 75.67 percent in 1998-99 and has stayed around this level since then.

An important development in RMG sector of Bangladesh was the growth of knitted garments export in the early 1990s. The garments industry was almost completely dominated by woven garments during the 1980s.Export of knit wear to the tune of US \$ 131.20 million was the first major consignment of knit RMG export from Bangladesh. After this knitwear export from Bangladesh grew rapidly; during the ten year period 1993/94-2003/04 the annual growth rate of knitwear export was about 23 percent, which was higher than the annual growth rate of 10.6 percent achieved by the woven garment during this period.

\section{Favorable Trade Environment In Bangladesh /Causes Of Mushrooming The Garments In Bangladesh:}

Two factors which played very important roles in the growth of the RMG industry in Bangladesh were:

- A favorable condition created by the MFA Quota system.

- Low wages of Bangladesh.

How these two factors have contributed in this sector will be discussed here.

Up until the early 1960s, the apparel industry in the developed countries like the US and UK relied on domestic subcontracting; cutting \& stitching operations were subcontracted to the small garment factories mostly relying on the use of cheap female labor, while large scale merchandising was undertaken by larger firms. Subsequently, as industrial wages began to raise, the apparel retailers in the developed countries; in most cases, such out sourcing took the form of subcontracting arrangement between the retailer in the developed 
countries \& garments manufacturer in the developing countries. The retailer in the developed countries placed work orders to the off-share garment manufacturers often through buying agents, and they also helped the garments makers in various ways to produce and ship the merchandises. Such subcontracting reduced the risk of doing business with foreign partners since it did not require any direct investment. In essence, it was a triangular trade between the garment manufacturers and the foreign buying agent on the one hand, and the retailer and the buying agent on the other.

As an LDC Bangladesh enjoyed the quota-free status in the 1970s and wages were also low. These two features attracted quota-hopping foreign producers to Bangladesh who collaborated with Bangladeshi entrepreneurs to export garments to North America, The EU and elsewhere. Daewoo, a major South Korean apparel exporter, collaborated with Desh Garments of Bangladesh in 1980 and this resulted in the first major consignment of RMG export from Bangladesh. The simple technology of making garments, basically involving 'cutting \& making' (CM), together with relatively low investment cost, made easier for the Bangladeshi entrepreneurs to move into this industry, and rapid growth took place, as mentioned earlier.

These favorable external market conditions, together with low labor cost, were two important factors which favored the rise of the RMG industry in Bangladesh. As noted above, both the number of firms in the industry and of export grew rapidly.

Even though Bangladesh enjoyed the quota free status in the North American market, its exports were subject to the payment of import duties. However, in the EU market, Bangladesh was not only exempted from MFA quotas but also enjoyed preferential market access to Bangladesh garments Exports. Thus, Bangladesh export of garments enjoyed quota -free and duty free access to the EU market. This was another important factor which contributed to the emergence of the RMG sector in Bangladesh.

However the favorable market situation was jolted in 1985 when several importing countries, most notably the US, imposed MFA quotas on Bangladesh's Garments exports. This resulted in a temporary slowdown in the growth of the number firms in the industry and also the export value. Between 1985-86 and 198889 the number of firms increased from 744 to 754 , which is a much slower growth compared to 1979/80$1984 / 85$ period when the number of the firm increased from 47 to 632 .

Since RMG industry catered to the demand of a global market, its growth was not constrained by the limited size of the domestic market. Unlike the jute goods and tea, world demand for Bangladesh's garments was growing rather than declining. This was particularly true when Bangladeshi garments export were not restrained by MFA quotas.

\section{1: METHODOLOGY USED IN THE STUDY:}

This content discusses about the present socio-economic status of the garments workers of Bangladesh. Of course we got some secondary data with particular references from internet and various publications. But only primary data have been used in this study.100 garments workers have taken as random sampling basis from Rampura and Badda areas of Dhaka. A detailed questionnaire has been made for collection of primary data focusing on major research questions particularly their income, job security, their accommodation, education of their spouse, children, compliance etc. Most of the questions are designed to get a complete scenario of the garments workers of Bangladesh. A stratified sampling technique has been used for selection of the sample in a manner that ensured an acceptable level of confidence. The ratio of the workers Male: Female was 9:11 and their age limit was 18-35 years. 90 per cent of the workers are from helper to operators .Others are supervisors, technicians, etc. Their education level is from primary to secondary level where 57 per cent workers are only able to write their names. 36 per cent of the workers are living in the slums and others are in the match sift houses. Only 62 per cent workers are sending their children to schools.

\section{Result and Discussion:}

Bangladesh is the hub of garments industry which has there been made by the garments workers of Bangladesh, for which they have to spend not only their time, labor but also their valued lives indeed. The poor workers have grown up the mercury of the GDP of the country, which resulted the development of the country not only economically but also in socioeconomic aspect. Presently the garments workers are socioeconomic status can be describe as follows:

1. Their income

2. Job security

3. Their accommodation

4. Education of themselves \& their children

5. Their savings, bank deposit

6. Their Recreation 
7. Their culture

8. Social Status

3.2 THEIR INCOME:

The garments workers are earning their breads by very hard labor. They render to the owners from the dawn to midnight. Sometimes, they have to work even for more than 24 hours without rest (they get breaks for their snacks, which are arranged by the authority) during the emergency shipment. Of course they are still ill paid, notwithstanding the different labor revolution for various times. In 2006 there was a huge movement in the garments industry where a lot of factories were gutted, vandalized the infrastructures for their various points of demand. Amongst those the first point demand was to increase the minimum salary in the entry level at least 3000/-(TK three thousand) per month .Later, govt. had fixed that 2200/-(TK two thousand two hundred) per month but later the BGMEA fixed it only TK 1667 (one Thousand six hundred sixty seven) per month by a tri lateral agreement (BGMEA, Bangladesh Govt., \& Labor Union of garments workers) which is final to concluding the movement so far.

On the field work, working with the questionnaire it was randomly found by the visitor that some workers are not getting this amount also from the factory owners. They have no holidays sometimes, they are forced to work in the holydays; their salaries are being paid one month later by showing different causes. Reduction of wages, attendances are in the common practices in the garments floor.

\subsection{JOB SECURITY:}

The garments workers have no job security yet. Any time without any reason they may be suspend, demotion, transferred even sacked from the company. Though there is a clause in the service rule that, the sacked employee should get at least one month salary from the company if he/she is sacked from the company without any cause (surplus, lack of works) but in fact, the due salary is not given sometimes. Very few companies abide by the rules of Govt., BGMEA. Each company has its own rules as the company like to have it.

\subsection{THE ACCOMMODATION OF GARMENTS WORKERS:}

All of the garments workers are ill fed and ill clad. Hardly can they spend for their accommodation after purchasing their food staffs. They cannot be a chooser rather live in an area only to stay alive. In our field work we have found that most of the garments workers are live in the rented slums, the room is 10 feetX12 feet, roofing by corrugated iron sheet or other thatching materials. Common unhygienic bath, kitchen for 8-10 family, shortage of water, crude electricity line etc. Monthly rent each of the room is Tk.1800 (one Thousand eight hundred).

Following problems have been chalked out during our investigation in the accommodation of the garments workers:

1. Lack of required spaces where a family can live easily with the other family members.

2. Tremendous crisis of water for which they cannot meet their required demand.

3. Indiscriminately power interruption, for which they cannot perform their daily works even their children, cannot make their lessons regularly.

4. Crisis of cooking place as they have to fight with others as there are 2 ovens (Natural gas oven) for 8-12 families.

5. No privacy at least which required for a man/family

6. Sound pollution for which the environment is not fit to live in normal life.

7. Serious problem in sanitary \& sewerage system; which makes the whole dwelling place a distressing environment for humanity.

8. The dwelling place where the garments workers live people from different professions also live there. There are rickshaw pullers, drivers, hawkers even the drug smugglers, prostitutes also live there. This is a strident place. Most of the criminals hide in that type of places where the law enforcing forces, miscreants budge always indiscriminately.

9. The place where the garments workers live is somewhat grimy. Most of their residential were found where the garbage of the city is dumped or where the area is putrid near by the big canal, drain or big ditches which are filled with putrid materials.

\subsection{EDUCATION OF THE GARMENTS WORKERS AND THEIR CHIELDREN:}

The garments workers are in low profile regarding the academic education. In the field work most of the female workers only can write their names \& address, most of them left the school after primary education. Few of them have gone to class VIII. We have conducted the survey within 100 workers where only two were found had attended SSC but not passed. The following reason can be outlined the causes of less education amongst the garments workers:

a) Poverty-Most of the guardians of the garments workers are poor. They prefer to think job is better than education. 
b) Ignorance-Most of the guardians are also illiterate. They think female education will not bear a good result to their family rather working in the garments factory will bring some money which will help them to run the family smoothly.

c) Easy accessibility of job: To be a garment worker is very easy. Anybody may have a job overnight if he/she tries which makes the young people to get involve without difficulty in this industry.

d) System of the society: It was also found that some guardians have disclosed that, they had allowed their wards to get involve to the service by the inspirations from others.

e) Dowry system: It is the system of the society that, most of the guardians claimed that they would need huge amount of money in the marriage of their female children (for dowry), who are working in the garments factories. They are earning for themselves as they are keeping the money in the bank for their future. But talking with the workers separately we found very few workers who are keeping money in the bank for their future excepting that, we found some NGO members amongst them which numbers are insignificant.

Almost all of the garments workers are outsiders. They return homes at night -means they have no scope at least to guide their children for education. Most of their children are going govt. primary schools; some NGO's school (BRAC, PROSHIKA, and UCEP etc) for their education. Some portions also take education in the various kindergartens.

We have found in our survey that, $87 \%$ of garments workers send their wards to schools while other $13 \%$ don't showing various causes as like below

-There is none to help in the household work.

-The elder one(son/daughter), who is supposed to go to school has to take care of his/her younger brothers \& sisters.

-We tried but they are not willing to go to school as we are outsider for the whole day.

-We can't afford the cost of education rather we prefer to engage him/her to some work which will make our family run smoothly.

-None is there to take care of them whether go school or not, they meet with the other notorious children, cannot pass the exam \& finally going school is totally stopped.

On the other hand, out of $87 \%$ garments workers' children who are going to school or other educational institutes, $73 \%$ of there are in the primary level, $19 \%$ are in the High schools \& only $8 \%$ have crossed the SSC and none was found HSC passed or above.

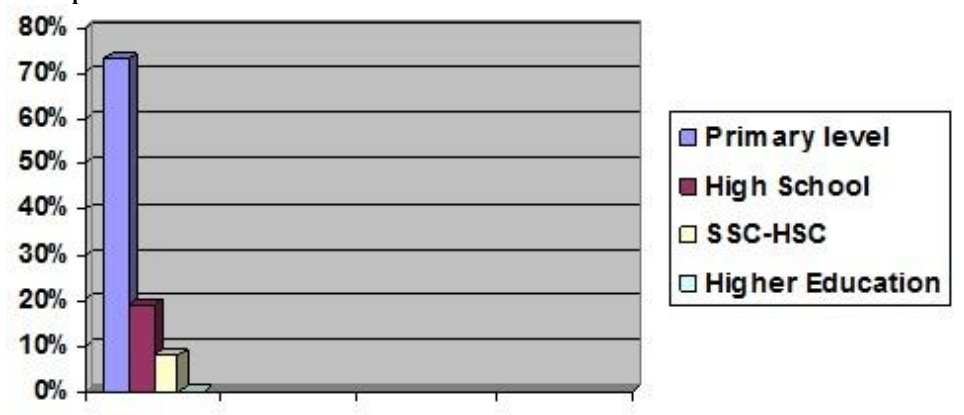

Figure 1: Education level of the garments workers' Children

\subsection{THEIR SAVINGS \& BANK DEPOSIT:}

Garments worker are not well-enough as they can hardly accomplish their needs by their earnings. It will not excess to say that they are always in the debit account. Nonetheless, we have some workers are VO members of the NGO's. They deposit their savings in that organizations. $41 \%$ workers are VO members of those NGOs (BRAC, PROSHIKA, ASA etc).Most of them are female workers. They also draw loan with the very high rate of interest from those NGOs. Only $6 \%$ have regular bank deposit scheme such like fixed deposits \& others. Interestingly we have found that more than $45 \%$ of the workers have insurance policies like life insurance, Pension Bima, Marriage Bima (Insurance for the Children which will be helpful in the marriage for the same in future).

A group organization was found composing 18 members, which has savings more than TK 140000 (One lac forty thousand) whose are willing to purchase a piece of land in Dhaka in future. They also are ready to purchase some three wheeler rickshaws to rent those, to increase their amount rapidly. They claim that, some more persons are willing to get the membership but in vain fearing future difficulties. Two workers said that they had sent their sons abroad from their savings and taking loan from others.

\subsection{THEIR RECREATION:}

As human being we must need amusement in our leisure time, to refresh the mind; to work productivity is the ultimate goal. But, hardly a garments worker can manage time to have the amusement. Even in the holyday they have to work sometimes. When there is full rush for works, they have to work day-night (of 
course, they get some benefits for that extra work which is called overtime).In holydays, when they get time they go to enjoy cinema or to parks with their near and dear ones. They also visit their village homes to see their parents and others. In the holyday they enjoy video by their own arrangement, cook rich foods and go to near about shopping to purchase their necessities. We have found some difficulties regarding the holyday in some families where husband -wife both are garments workers in the different factories. They have different weekly holydays (for example Husband's holyday is in Friday but wife getting the same in Monday) for which they can't enjoy themselves as they like to do.

It's also noticeable that they wear colorful dresses in our various national days like Pohela Baishakh $\left(1^{\text {st }}\right.$ day of Bangla year), 16th Decembers etc. Some factory owners arrange yearly picnic for the workers and other staffs, where they enjoy different cultural programs and indoor games.

In our survey there was a question common to all 'which types of recreation do you like?' In their answer we found that, $46 \%$ like to enjoy Cinema (in Cinema hall or video in the home), $39 \%$ like to go outside (with their dear ones) 9\% like shopping 3\% and 3\% have no special recreation plan at all. They like to gossip with neighbors \& take rest by sleeping in the house.

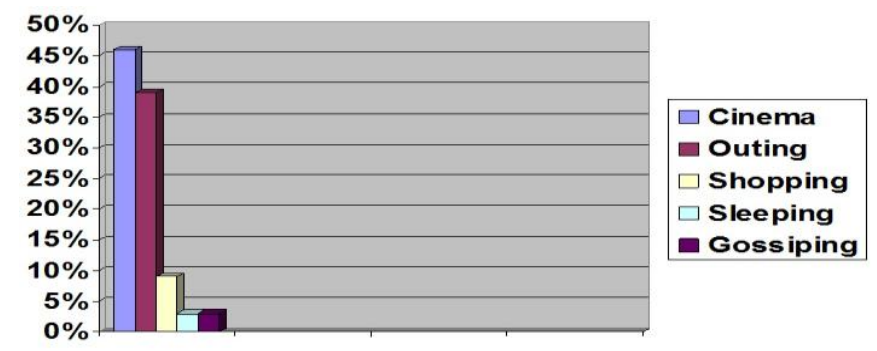

Figure 2: Recreation chosen by Garments Workers

\subsection{THEIR CULTURE \& SOCIAL STATUS:}

Culture includes vast things. Here we will mean customs for culture of Garments workers

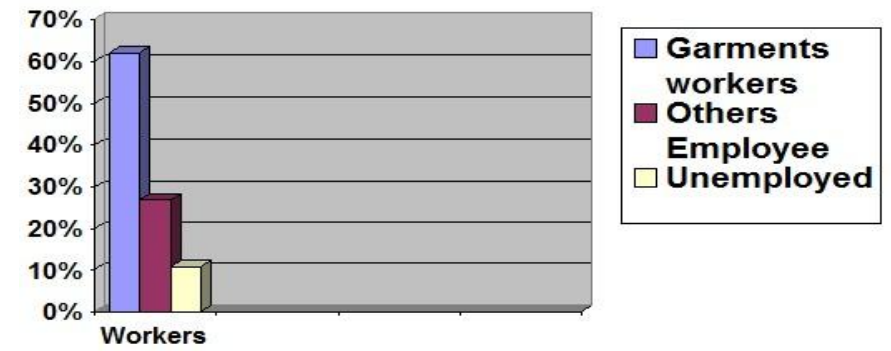

Figure 3: Profession of Garments workers' Spouse

It will not be an exaggeration to say a custom namely 'Garments Culture' because garments industrialization is the lifeblood of economy of Bangladesh. The garments people are doing restless work from dawn to midnight to make fabulous growth in our wealth. In true sense, they have no specific time to think about their amusement separately. They mix within themselves. Most of them get marriage with garments workers (May there be termed as 'Garments workers family').We found in our survey that, $68 \%$ of the garments workers have got marriage garments workers whereas $27 \%$ of them work in the same factory or industries. Garments workers live in densely populated areas. Generally they live semi-pucca house or in huts. About 6-8 workers live in a mess who are unmarried or married bachelor or divorced. Some well established family (3-4 persons of a family when make income) also live independently renting a house or even a flat. Garments workers mainly send their children in govt. primary schools, madrashas or to NGO's schools for education. Some portion also sends their children to private kindergartens. Garments people are always in rush. They have no time and even scope to mix with others professionals in fact. They wear very colorful cloths. Mainly they prefer cheap cotton cloth to avert sweating due to longstanding working inside the factories.

They suffer from various diseases including malnutrition. Still they are ill paid. On the other hand, they are not paying regularly. Some of the factories do compromise with the rules and regulations while others are not, showing different causes. Nowadays, it also makes newspapers a headline that 'garments workers barricades traffics for their dues' which is painful. There was a huge chaos in 2006 which caused a lot of causalities and damages of garment assets, goodwill in home and abroad.

3.9. Recession \& our RMG: The economic downturn of the world has started worldwide which caused impede in various aspect of our RMG sector. Following are the main points where recession already effected. 
1. Buyers have already cut off their orders from Bangladesh for which many small factories and buying offices have shut down.

2. Many workers already became jobless .Their wages are in due to the garments owners for which they can not lead their livelihood.

3. Still the govt. of Bangladesh is completely silent about the taking measure for bail out from the recessional effect from the garments sectors. If Govt. does not take any measure then, number of unemployment will be increased in the society. Hence, it is to be feared that the social crimes will increase rapidly.

4. If the people from garments sector lose their job than purchasing ability of some people who are dependent directly on the RMG sector will decrease. As a result, the factories which are producing other commodities will produce lesser quantity than before or will shut down gradually which will result more unemployment in the country.

3.10. How we can increase and ensure the facilities of our garments workers (Their opinions): In the questionnaire there is question for all what can be done for the betterment of the garments worker? In reply many people gave their consents from their sides. These are the followings:

1. Still garments workers are ill paid. Govt. should ensure their wages in regular basis on right time. Their salary structure should be revised with present condition of the market.

2. There are many irregularities in the factories such as physical torture, abuse, etc which should be checked from the govt.

3. The factory owners make them compel to work in the holiday, even in the Eid day but they randomly cut salary in the name of late coming, bad performance, bad quality etc which should there be minimized.

4. BGMEA, BKMEA are always saying about compliance issues for the workers. In fact, in our observation we found very little regarding they deserve.

5. Child care with Schooling system may there be introduced for the garments workers' children in which BGMEA,BKMEA ,Bangladesh govt. will take responsibly to ensure the education up to the mark.

6. Facilities should be increased to maximize the recreational facilities of the garments workers by the factory owners, Govt .others organs related with garments.

[1] Abdel-Latif, Abla M. (1993). "The non price determinants of export success or failure: the Egyptian ready-made garments industry, 1975-1989" World Development, Vol. 21, No.10, pp.1677-1684

[2] Ahmed, Razib (2009). Impact of Global Economic Recession on Nepalese Economy,http://search.msn.com/results.aspx?srch=106 \& Form=Effect of economic recession of RMG sector of Bangladesh.

[3] Asiatic Society of Bangladesh (2006) "Garment Industry" in Banglapedia, Asiatic society of Bangladesh, Retrieved August 7, 2006 fromhttp://banglapedia.org/HT/G_0041.HTM

[4] Bangladesh Garments Manufacturers And Exporters Association (BGMEA)-Government recognized trade body of the garments factories of Bangladesh, <www. bangladesh garments. Info>accessed during the period 2003-2007

[5] Bhuiyan, Z.A. (2008). Marketing Prospect of Product Design and Development of Bangladesh, Seminar Paper with Netherein University, Germany.

[6] BBS (1989) "Report on Labor Force Survey 1989", Bangladesh Bureau of Statistics, Government of Bangladesh, Dhaka

[7] BBS (1991) "Report on Labor Force Survey 1991", Bangladesh Bureau of Statistics, Government of Bangladesh, Dhaka

[8] Bangladesh Institute of Management (1999) "Impact study on Enforcement of Labor Laws Relating to Women Workers in the Garments Industry", BIM, Dhaka

[9] BGMEA (2007) Directory of the Bangladesh Garments Manufacturers Association 2006-07

[10] Bhatty ,Z.(1980) "Economic Roles and status of Women: A case study of Women in the Bead industry in Allahabad", Working Paper, ILO, Geneva.

[11] Bhattacharya, Debapriya (2007).Bangladesh's apparel Sector in Post-MFA period: A benchmarking study ongoing Restructuring Process, A publication by Center for Policy Dialogue (CPD)

[12] Export promotion Bureau, Bangladesh (EPB)www.epbd.com/,accessed during 200-2007.

[13] Haider, Mohammed Z.(2006) "Export performance of Bangladesh textile and garments industry in major international market"

[14] Hamid,S.(1989) “women's Non-market works and GDP Accounting:The case of Bangladesh”Research Report No.116,Bangladesh Institute of development Sudies,Dhaka

[15] Haque, Ahasanul (2002).Global Marketing of Readymade Garments Products from Bangldesh: Market Prospect and Challenges., Pakistan journal of Applied Science 2(10): 975-979

[16] Latif, M.A.(1994) "The Program Impact on Current Contraception in Bangladesh" The Bangladesh Development Studies, Vol.XXII,NO.1.

[17] Mainuddin, Khandaker(2000). Case of Garments industry of Dhaka, Bangladesh, Urban and Local Government background series, No.6 (Washinton, D.C., World Bank)

[18] Mukta,Z.H.(2001) The rights of Female Workers (in Bengali),Karmajibi Nari,Dhaka

[19] Morshed, M.Monjur (2007). A study on labor rights implementation in readymade garments (RMG) industry in Bangladesh: Bridging the gap between theory and practice, 2007, University of Wollongong, University theses collection.

[20] Shikder,N.B.(2002) "Women Garment Workers In Bangladesh "doctoral Thesis in the Department of Sociology, University of Manchester, UK

[21] Shimu,S.D.(1999) Garments Workers: Movement and Struggle(in Bengali),Nari Grantha Probontona, Dhaka

[22] Zohir, S.C.(2001) "Social Impact of Growth of Garments Industry in Bangladesh "The Bangladesh Development Studies, Vol.XXVII,No.4,pp 41-80 